\title{
PLANTS
}

\section{THE COMMON BUTTERWORT AND \\ ITS RARE OCCURRENCE IN SOUTHERN SASKATCHEWAN}

H.E. MANN, Biology Department, Sir Wilfred Grenfell College, Memorial University of Newfoundland, Corner Brook, NF A2H 6P9 and M.V.S. RAJU, Biology Department, University of Regina, Regina, SK A4S OA2

The common butterwort (Pinguicula vulgaris $L$.) is a circumboreal northern hemisphere species belonging to the family Lentibulariaceae. ${ }^{14}$ It grows abundantly in the Arctic and boreal regions of Canada. ${ }^{7,12}$ Although it is commonly present in the north and eastern parts of Saskatchewan, it is absent from the prairies of Saskatchewan and Alberta. $7,8,12$ However, it occurs in a small area (north

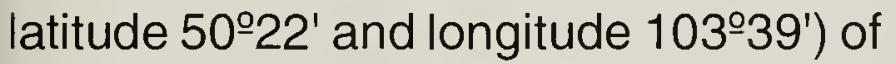
Strawberry Lakes, about $70 \mathrm{~km}$ from Regina or $35 \mathrm{~km}$ south of Indian Head. ${ }^{4,5,9,10}$ There it grows close to surrounding aspen-poplar groves in areas where there is considerable water seepage and ground water discharge along the sand outwash of a dry lake bottom. ${ }^{5}$ In the exposed area, hummocks occur abundantly where many grasses, mosses and other herbaceous floral elements thrive. The hummocks form important sites in the region, facilitating the growth of this herbaceous butterwort.

Early in the growing season, when the temperature is often below $0^{\circ} \mathrm{C}$, the over-wintered butterwort plants show signs of growth. These "winter resting buds" or "hybernacula", are composed of compacted scaly leaves. At their bases occur many brood-buds (plantlets, gemmae, vegetative buds)
(Figure 1A,B). ${ }^{9,13}$ As growth proceeds, the scaly leaves of such plants expand to form rosettes of spread-out leaves (Figures 1C, 2A). During the expansion of scales that develop into leaves, the small plantlets get detached, often floating on spring- melted water. Such small buds, after the water level has receded, become established on hummocks and grow into adult plants. The plants developed from original budlike plants and also from brood-buds are scattered individually or in clusters on the hummocks (Figure 1C).

Flower buds, each supported by a stalk of scape, emerge from the centre of the rosette in late April and early May. Flowers are elevated by the elongation of their stalks (Figs. 1D, 2A). The number of flowers per plant may vary from 1 to 7 , one or two being the most common. Flowering does not occur in one-year-old plants. Plant rosettes vary considerably in size and age. Usually, the smaller plants are younger, and about 2-3 years old, while the larger plants are usually more than 3 years old. Smaller plants usually produce a single flower, the larger ones two or more. Flowers are bisexual, each consisting of 5 greenish or purplish sepals, 5 pink or purple petals, two stamens and a centrally placed pistil. The petals are fused laterally (gamopetalous), and the 
base of the flower has a characteristic tubular structure representing the modified parts of petals, called the spur (Fig. 1D, Fig, 2D). The spurs accumulate secretory fluids often attracting a variety of insects, such as thrips, flies, bees, wasps, etc. Despite many insect visits, the flowers are predominantly selfpollinated with a very low probable occurrence of cross-pollination by insects. ${ }^{10,12,13}$ On plants, which produce many stalked flowers, the flowers mature in a sequence from the first formed to the most recent. The first developed flower is the most successful one in having early pollination and maturity, and also in producing a large number of viable seeds.

Flower abnormalities in the Strawberry Lakes population of the common butterwort are quite common. The first formed flowers usually contain normally developed floral parts (Figs. 1D, 2A). Some later-formed flowers, on the other hand, show many abnormal features (Fig. 2D-J). In addition, the flowers show the phenomenon of fasciation, which includes fusion of flowers and/or floral stalks (Fig. 2l,J). Occasionally, a flower may develop double spurs (Fig. 2F) or contain three stamens (Fig. $2 \mathrm{H}$ ). In a few cases, the flowers may not develop spurs, the presence of which is a characteristic feature of the genus Pinguicula.

The common butterwort is known to exhibit the insectivorous habit by trapping and digesting insects, and the leaves are well adapted for it. ${ }^{1,3,13}$ On the upper surface of mature leaves occur a large number of glands which are classified as "stalked" and "sessile". Both types are capable of secreting fluids. Each gland has a multicellular head, and is supported by two-celled base (Figs. 1E, 2B,C). The two supporting cells in one type elongate to form an obvious stalk to support the gland. In others the head is not elevated because of lack of elongation of the two stalk cells, and they are designated as stalk-less or sessile glands (Fig.2B,C). In addition to being different in form, stalked and sessile, the glands also are reported to differ in function. ${ }^{3}$ The stalked glands secrete sticky substances which aid in the capture of the intruding insects (Fig. 1G). ${ }^{3}$ The sessile glands, on the other hand, secrete substances that contain digestive enzymes. Such enzymes digest the captured insects and release nutrients, especially nitrogenous, which are eventually absorbed by leaves of the plant. ${ }^{3,13}$

Although the common butterwort occurs abundantly in the boreal and parkland areas of Saskatchewan, there are two important factors that make it an important species in the prairie region. Firstly, the species is confined to a small Strawberry Lakes area of the glaciated prairies of southern Saskatchewan where it has been isolated in its "refugium" since the melting of the glacier about twelve thousand years ago in this location. ${ }^{2,11}$ Isolated populations tend to diverge genetically with time making this a rare and unique opportunity for insights into the process of evolutionary change. Secondly, it is but one member of a community of other northern species which were also left behind during the northward postglacial vegetation advance. These include mosses (Drepanocladus uncinatus, Mnium addine, Tomenthypnum nitens), primitive vascular plants such as dwarf scouring-rush (Equisetum scirpoides), spike moss (Selaginella rupestris) and some low growing herbs such as Adder's mouth (Malaxis monophylla), hooded lady's-tresses (Spiranthes romanzofiana), oblong-leaved gentian (Gentiana affinis) and others. The habitat and the community of plants it 
harbours appear to be a unique "oneof-a-kind" rare situation, which deserves recognition and protection as a glimpse into the natural history of our past.

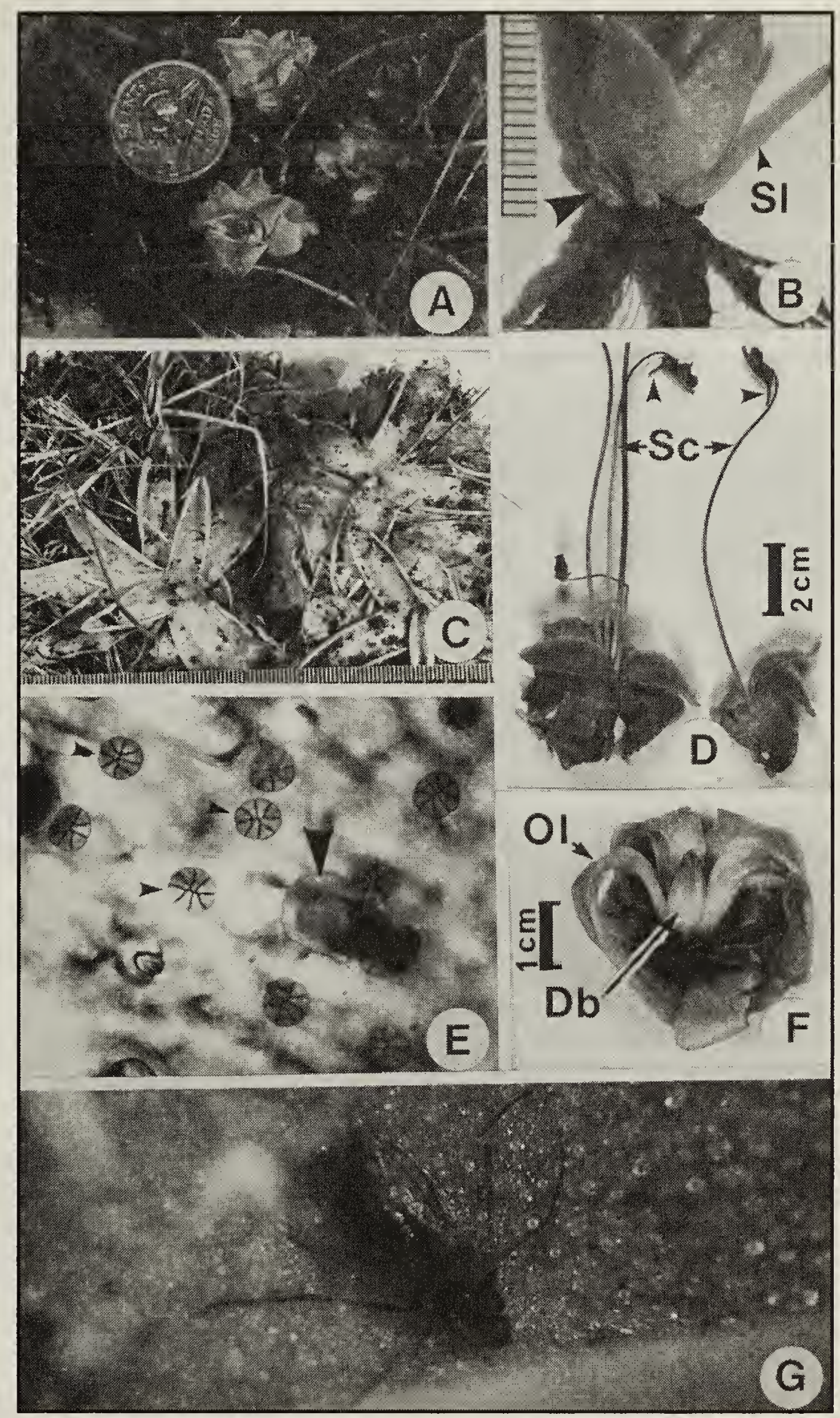

Figure 1. Growth and morphology of Pinguicula vulgaris L. (common butterwort) collected from Strawberry Lakes. A. Plants growing early in April on grassy hummocks containing mosses and grasses. B. A plant isolated from the hummock to show scaly leaves (SI) and dead roots from previous year. Arrow points at vegetative (asexual) bud at the base of the plant. (Scale in $\mathrm{mm}$ ). C. Plants growing in clumps in July to show the spread-out or rosette of leaves developed from scaly leaves. (Scale in $\mathrm{mm}$ ). D. Plants with expanded leaves showing flowering scapes (Sc). Arrows point at spurs of flowers. E. Upper leaf surface with sessile (small arrow heads) and stalked (large arrow head) glands. $x$ 250. F. A plant in late July with outer normal leaves $(\mathrm{OI})$ and centrally situated over-wintering brood or dormant bud $(\mathrm{Db})$ with scaly leaves. G. Leaf surface with a trapped insect. $x>0$. 


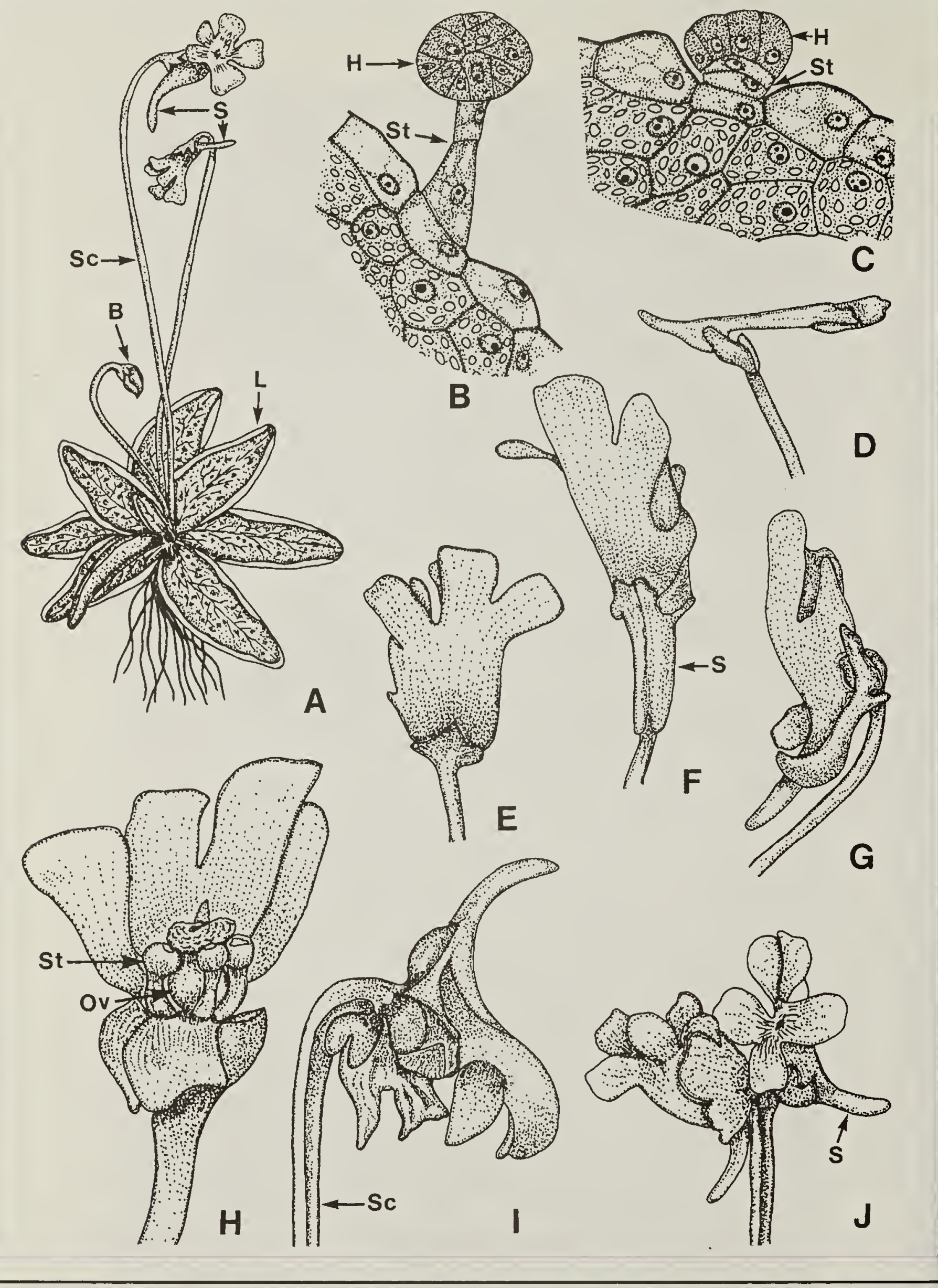

Figure 2. Drawings of different parts of Pinguicula vulgaris L. plant. A. A plant collected in mid-May with a rosette of leaves $(L)$ and centrally placed three floral scapes, two with flowers showing spurs (S) and one flower bud (B). $x$ 1/2. B. A mucilage secreting gland with a multicellular head $(H)$ and a two-celled stalk (St). x 50. C. A sessile enzyme secreting gland with a multi-cellular head $(H)$ and a short two-celled stalk $(S t) . \times 50 . D$. An abnormal flower with no normally differentiated floral parts. $x$ 2. E. A flower lacking spur. $x$ 2. F. A flower with two spurs (S) fused together. $\times 3$. G. A flower with malformed petals and other floral parts. $\times 2$. H. A flower showing ovary (OV) and three stamens (St). $\times$ 3. I. A double floral scape (Sc) fused together and two flowers fasciated abnormally with a single spur. $x$ 2. J. Two floral stalks fasciated with two distinct flowers each with its own spur (S). $\times 2$. 
1. DARWIN, C. 1875. Insectivorous plants. Murray, London, United Kingdom.

2. GORDON, A. 1979. Geology of Saskatchewan - A historical approach. Western Extension College Educational Publishers, Saskatoon, SK. Pp. 1-67.

3. HESLOP-HARRISON, Y. 1978. Carnivorous plants. Sci. American 238:104-115.

4. JONES, G.J. 1964. Pinguicula vulgaris in southern Saskatchewan. Blue Jay 22:117-118.

5. JONES, G.J. and E.B.PETERSON. 1970. Plant species diversity in a woodland-meadow ecotome near Regina, Saskatchewan. Can.J.Bot. 48:591-601.

6. LOOMAN, J and K.F.BEST.1979. Budd's Flora of the Canadian Prairie Provinces. Agriculture Canada, Ottawa.

7. MAHER, R.V., G.W.ARGUS, V.L.HARMS and J.H.HUDSON. 1979. The rare vascular plants of Saskatchewan. National Museums of Canada, Ottawa, Canada.

8. MOSS, E.H. 1983. Flora of Alberta. University of Toronto Press, Toronto, Ontario, Canada.
9. RAJU, M.V.S. 1969. Development of floral organs in the sites of leaf primordia in Pinguicula vulgaris. Amer.J.Bot. 56:507-514.

10. RAJU, M.V.S. 1997. Pinguicula vulgaris L. - Phenology and Pollination. In Plant Form and Function (Bhatia, B., A.K. Shukla and H.L.Sharma, eds.). Angkor Publishers (P) Limited, New Delhi, India.

11. RITCHIE, J.G.1966. Aspects of the late-Pleistocene history of the Canadian flora. Pages 66-80 in The Evolution of Canada's Flora (Taylor, R.A. and R.A. Ludwig, eds). University of Toronto Press, Toronto, Canada.

12. SCHNELL, D.E. 1976. Carnivorous plants of the United States and Canada. Lebanon Valley Offset Company Incorporated, USA.

13. SLACK,A. 1980. Carnivorous plants. The MIT Press, Cambridge, Massachusetts, USA.

14. WILLIS, J.C. and H.K. AIRYSHAW. 1973. A dictionary of flowering plants and ferns. Cambridge University Press, London, UK.

Lavender is from 'lavo', Latin for 'to wash, because it was used by the Romans to perfume their bath water.

Primrose, is from primus, Latin for first - perhaps meaning the first "rose" as the blooms appear before roses flower. 